\title{
Role of New Immunophenotypic Markers on Prognostic and Overall Survival of Acute Lymphoblastic Leukaemia - A Systematic Review and Meta-analysis
}

\author{
Wesley Messias Santos, ${ }^{1}$ Amanda Fernandes Oliveira Costa,${ }^{2}$ Lucio Henrique Sousa Pinheiro, ${ }^{1}$ Nathanielly de \\ Lima Silva, ${ }^{1}$ Alex Freire Sandes, ${ }^{3}$ Marco Antônio Prado Nunes, ${ }^{4}$ Cristiane Bani Correa,${ }^{5}$ Carlos Arthur Cardoso \\ Almeida, ${ }^{6}$ Geydson de Santana Cruz, ${ }^{4}$ Divaldo Pereira de Lyra Junior, ${ }^{1}$ Dulce Marta Schimieguel ${ }^{1}$ \\ 1. Department of Pharmacy, Laboratory of Hematology, Federal University of Sergipe, São Cristóvão, Sergipe, Brazil; 2. Department of \\ Clinical Medicine, Laboratory of Hematology, Medical School of Ribeirão Preto, University of São Paulo, São Paulo, Brazil; 3. Fleury Group, \\ Hematology Division, São Paulo, São Paulo, Brazil; 4. Department of Medicine, Federal University of Sergipe, Aracaju, Sergipe, Brazil; \\ 5. Department of Morphology, Federal University of Sergipe, São Cristóvão, Sergipe, Brazil; 6. Nursing and Pharmacy School, \\ Federal University of Alagoas, Maceió, Brazil
}

\begin{abstract}
ntroduction: Acute lymphoblastic leukaemia (ALL) is a haematologic malignancy with variable survival rates and prognosis. New immunophenotypic markers can be directly associated with prognosis in several subtypes of ALL. Methods: Following PRISMA guidelines, a systematic review of PubMed, Scopus, Science Direct, Web of Science and Cochrane Library was carried out from $2012-2016$. Results: The search resulted in 23 articles, and nine of these articles met the inclusion criteria. The methodological quality was evaluated by STROBE tool that showed eight articles scoring $>90 \%$, revealing high methodological quality. The included studies evaluated 11 new immunophenotypic markers in a total of 765 patients with ALL. From these 11 markers, eight were associated with poor prognosis (CD86, CD135, CD117, CD133, CD71, CXCR4, VLA-4 and CD38+/CD58-), and three with good prognosis (CD304, CD27 and CD200). Meta-analysis demonstrated that CD71+ and absence of phenotype CD38+/CD58- in ALL have been associated to increased relapse $(0.23 ; 95 \%$ confidence interval [Cl] 0.03, 0.43), resulting in decreased overall survival $(0.23 ; 95 \% \mathrm{Cl}-0.05,0.51)$ at 60 months. Conclusions: CD38+/CD58- phenotype is a predictor of mortality for patients with ALL. This study reaffirmed immunophenotypic markers as independent prognostic factors that could be included into clinical protocols, risk stratification and therapeutic guidance.
\end{abstract}

\section{Keywords}

Immunophenotyping, acute lymphoblastic leukaemia, prognosis, survival, immunophenotypic markers

Disclosures: Wesley Messias Santos, Amanda Fernandes Oliveira Costa, Lucio Henrique Sousa Pinheiro, Nathanielly de Lima Silva, Alex Freire Sandes, Marco Antônio Prado Nune, Cristiane Bani Correa, Carlos Arthur Cardoso Almeida, Geydson de Santana Cruz, Divaldo Pereira de Lyra Junior and Dulce Marta Schimieguel have no conflicts of interest to declare in relation to this article. Acknowledgements: This study was supported in part by the Coordenação de Aperfeiçoamento de Pessoal de Nível Superior - Brasil (CAPES - Finance Code 001), and by Programa Pesquisa para o SUS - CHAMADA MS/CNPq/FAPITEC/SE/SES - No 06/2018 PPSUS-Sergipe. The authors thank the authors of the studies included in our meta-analysis for providing additional information about their studies at our request.

Review Process: Double-blind peer review.

Compliance with Ethics: This study involves a retrospective analysis of data and did not involve any studies with human or animal subjects performed by any of the authors.

Authorship: All named authors meet the criteria of the International

Committee of Medical Journal Editors for authorship for this manuscript

take responsibility for the integrity of the work as a whole and

have given final approval for the version to be published.

Received: 25 July 2019

Accepted: 12 November 2019

Citation: European Oncology \& Haematology. 2019;15(2):113-20

Corresponding Author: Dulce Marta Schimieguel, Department of Pharmacy,

Laboratory of Hematology, Federal University of Sergipe, São Cristóvão,

Sergipe, Brazil. Zip Code: 49100-000. E: hematox2017@hotmail.com

Support: No funding was received in the publication of this article.
Acute lymphoblastic leukaemia (ALL) is a group of malignant haematological disorders characterised by accumulation of lymphoid cell precursors that replace normal bone marrow elements and inhibit the production of functional blood cells. ${ }^{1}$ ALL occurs in both children and adults, and more than one-half (56\%) of those diagnosed are $<20$ years old, with chemotherapy required as standard treatment. ${ }^{2}$ The 5 -year survival rate is $46 \%$ for patients aged $20-39$ years, $30 \%$ for those aged 40-64, and $15 \%$ for those aged $\geq 65 .{ }^{2}$ Despite the increasing importance of genetic characteristics and molecular biology in ALL classification, morphological and immunophenotypic analysis remain the main techniques used in the initial diagnosis of these disorders. ${ }^{3,4}$ Immunophenotypic analysis by multiparametric flow cytometry has been improved, and it is widely used in ALL diagnosis and treatment monitoring. It allows identification and quantification of abnormal cells, classifying ALL subtypes according to cell lineage and maturation stage. ${ }^{5-7}$ In addition, the study of minimal residual disease (MRD) by multiparametric flow cytometry allows to distinguish normal lymphoid precursors from residual leukaemic cells after chemotherapy, which helps to identify the risk of relapse. ${ }^{8}$

Although several prognostic factors have been described for adult patients with ALL and outcomes have improved considerably in recent years, a significant proportion of cases still relapse. It is hoped that by pursuing a better understanding of molecular mechanisms and resistance to chemotherapy, the identification of new immunophenotypic markers may be used to guide the development of new targeted chemotherapy or immunotherapeutic agents. ${ }^{9-11}$ 
Since there are no clear recommendations for the use of new markers in panels for immunophenotypic diagnosis in ALL, and their influence on determining prognostic features and survival is not used in clinical practice, a systematic review was performed aiming to identify relevant publications on the influence of the new monoclonal antibodies used as immunophenotypic markers in the prognosis and survival of patients with ALL.

\section{Methods}

A systematic review was performed based on a scientific research protocol describing the aims and methods used. Within the research limitations, this synthesis was performed according to the Preferred Reporting Items for Systematic Reviews and Meta-Analyses (PRISMA) statement. ${ }^{12}$ The question of this systematic literature review was: "Are there new immunophenotypic markers that may be used to define prognosis and survival status in acute lymphoblastic leukaemia?"

\section{Search strategy}

The literature search was conducted using PubMed, Science Direct, Web of Science, Scopus and Cochrane Library databases for articles published from 2012-2016. The investigation started in 2012 according to the last EuroFlow consortium update for ALL immunophenotyping panels. ${ }^{6}$ In addition, the reference lists of relevant papers were searched for additional ALL studies. The search consisted of a range of pertinent terms: antigens, CD (MeSH); antigens, differentiation (MeSH); biological markers (MeSH); tumor markers, biological (MeSH); prognosis (MeSH); survival rate (MeSH); survival analysis (MeSH); precursor cell-lymphoblastic leukemia/ lymphoma (MeSH); and acute leukemia.

\section{Study selection}

The articles found were compared with the following defined inclusion criteria to determine the relevance of the study: (1) papers published from 2012-2016; (2) articles published in English, Spanish and Portuguese; (3) articles that used immunophenotyping by flow cytometry in their methodologies; (4) articles assessing monoclonal antibodies not included in the consensus diagnostic panels for ALL (EuroFlow consortium):13 (5) articles assessing monoclonal antibody combination, even those included separately in the consensus diagnostic panels for ALL (EuroFlow consortium); ${ }^{13}$ (6) articles assessing ALL cases; and (7) articles with available abstract and full text. Systematic and literature reviews, meta-analyses, editorials, conference proceedings and books were excluded from the study.

Two reviewers independently evaluated the titles and abstracts of the identified publications by applying the inclusion criteria. Potentially relevant articles were retrieved in full. The final inclusion of articles into this systematic review was based on agreement between both reviewers. In case of any disagreement between the two reviewers, a third reviewer inspected the full text article and finalised the decision of whether or not to use the article.

The methodological quality of each individual study was evaluated using the Strengthening the Reporting of Observational Studies in Epidemiology (STROBE) assessment scale which consists of 22 items. ${ }^{14}$ High scores meant that there was sufficient information and good design. STROBE was a highly feasible and applicable method to use for evaluating systematic reviews of observational studies.

\section{Data extraction and management}

From the included studies, the following information was obtained: journal of publication, The Journal Citation Reports impact factor, location, study design, aim of the study, number of samples analysed, age, ALL classification, most incident subtype, immunophenotypic marker, cut-off value, prognostic value, gene mutation, first induction treatment protocol, follow up, survival, limitations, and STROBE scores. For inaccessible or incomplete full texts, authors were contacted for additional information.

\section{Statistical analysis}

A meta-analysis was performed for disease-free survival (DFS) and overall survival (OS) in ALL at 10,30 and 60 months to evaluate the influence of new immunophenotypic markers on prognosis and survival. DFS is defined as the period measured from the date of achievement of a remission until the date of relapse or death from any cause. It is only used for patients that achieved complete remission. Otherwise, OS is a measure from the date of entry into a clinical trial or from the date of diagnosis to the date of death from any cause..$^{15}$ The cut-off points of 10 months, 30 months, and 60 months were established due to the availability in Kaplan-Mayer curves in the studies analysed. Absence of immunophenotypic markers was considered as negative if the immunophenotypic markers had low expression, and as positive if the markers were expressed in high levels.

The statistical heterogeneity in meta-analysis was assessed using the Cochran Q test and quantified by Higgins $\left.\right|^{2}$ test. Null hypothesis was considered when studies included into the meta-analysis were homogeneous using Cochran Q test. Heterogeneity was categorised as a scale, whereby between $0-25 \%$ was classified as no heterogeneity, and $>25-50 \%,>50-75 \%$ and $>75-100 \%$ were considered as low, moderate and high degrees, respectively.

Following the heterogeneity analysis, the model to be used in each meta-analysis (the fixed effects model or the random effects model) was chosen. The fixed effects model assumes the effect of interest is the same in all studies, and the differences observed between them are due only to sampling errors. The random effects model assumes the effect of interest is not the same in all studies, but studies that are part of the meta-analysis result in a random sample of hypothetical amount of studies. A meta-analysis was then performed using a proportion of individuals who experienced the event of interest. The meta-effect estimates of the proportion of positivity, summarised with the respective 95\% confidence intervals, have been reported. The funnel graphs and regression testing of asymmetry were used to assess potential publication bias. The bias was considered significant at $p=0.05$. All analyses were performed by the programme $\mathrm{R}$ version $3.4 .3^{16}$ and the "Metafor" package. ${ }^{17}$

\section{Results}

\section{The literature search}

The literature search retrieved 10,209 articles. After screening titles and reviewing abstracts according to the inclusion criteria, we identified 23 potentially relevant articles that studied immunophenotypic markers and multiparametric flow cytometry (Figure 1). In the final analysis, nine studies were included in the qualitative synthesis of this review with a total of 11 markers.9.10,18-24 Two of them were used in a meta-analysis for 10-, 30- and 60-month DFS and OS.

\section{Study characteristics}

Results of the nine studies included in the final analysis are shown in Tables 1 and 2. For the purposes of this study, articles published since 2012 were selected (the date of the last EuroFlow Consortium update for ALL immunophenotyping panels). In the range of these years, nine studies were included showing the inclusion and exclusion criteria was 
Figure 1: Flow diagram for study identification

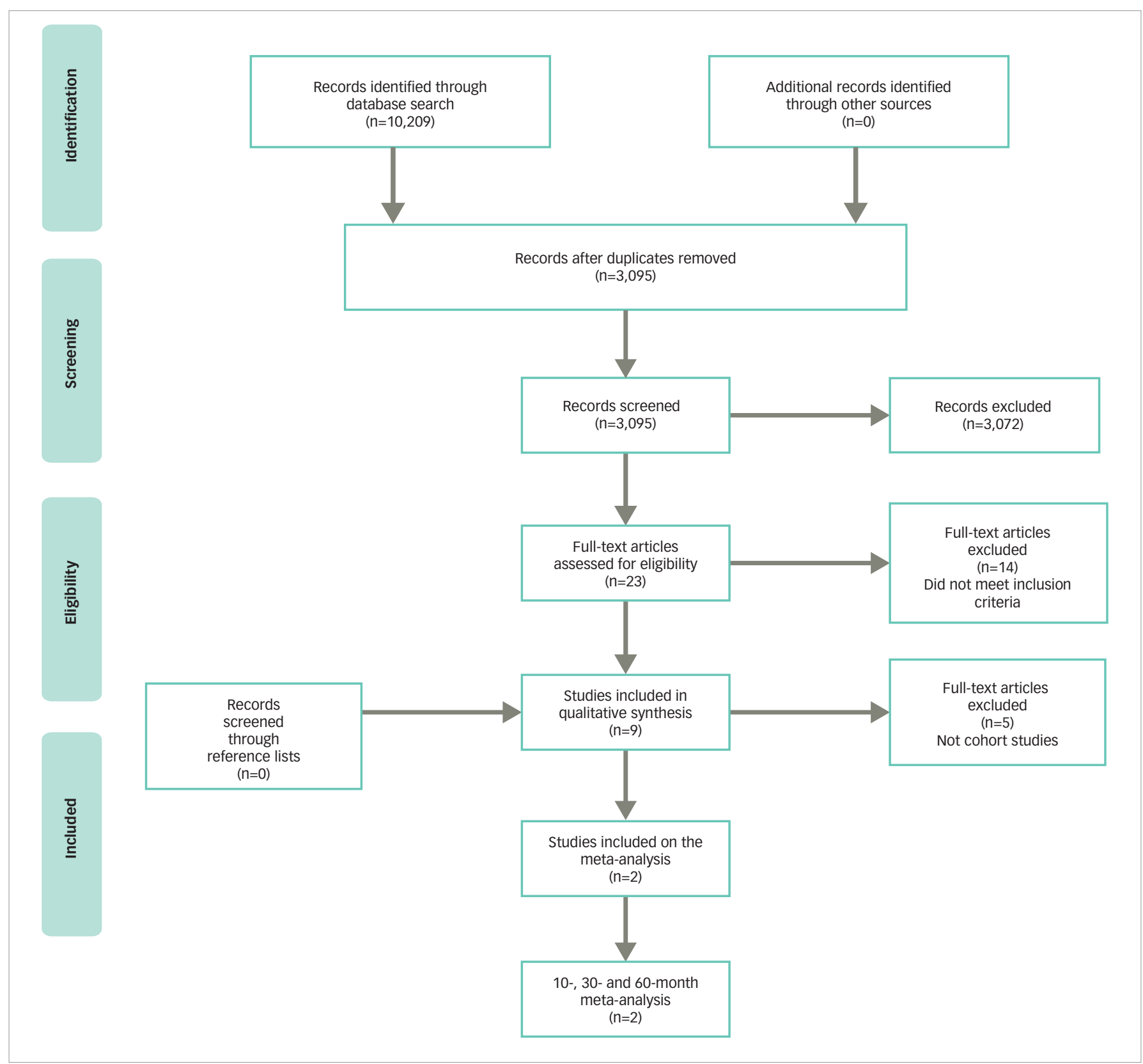

precisely applied into this study. Further, immunophenotyping data were collected at the time of patients' diagnosis, this way there was no treatment influence on the result. This is also the reason that the date of immunotherapy initiation was available. Sample size ranged from 25-196 patients with a total of 765 haematological samples analysed. 19,24 Four studies used The World Health Organization (WHO) ${ }^{20,22-24}$ diagnostic criteria and two used The French-American-British System to classify ALL cases. ${ }^{9.18}$ The other two studies classified patients only regarding B and $T$ cells, ${ }^{19,21}$ and one did not use any system to classify them. ${ }^{10}$ The most reported subtype in the articles was common ALL followed by precursor B-cell subtype. None of the articles presented patients with Phpositive ALL.

Selected studies were from seven different countries across five continents, and the Journal Citation Reports impact factor of the journals from which the articles came ranged from 1.060-3.181 (Table 1). Patients' age ranged from 0-82 years. A total of 556 patients were $<18$ years old. The expression of 11 different antigens was evaluated in all articles (Table 3). All nine studies were based on proving the impact of novel antigens on ALL prognosis while three of them were cohort studies that also ascertained the influence of these markers on patient survival. ${ }^{21,23,24}$ The most common chemotherapy regimen was based on the Berlin-Frankfurt-Münster protocol, ${ }^{25}$ although other alternative treatments were chosen by some other groups. ${ }^{21-23}$

The methodological quality of observational studies conducted with the STROBE tool showed that eight articles scored $>90 \%$, revealing a high methodological quality of the included studies. One article scored 19 points (86.4\%), ${ }_{1}$ four scored 20 points (91.0\%), ${ }^{10,18,23,24}$ and four scored 21 points $(95.4 \%), 9.19,20,22$

\section{Prognostic value and survival}

From the nine articles, six $x^{9,10,20,21,23,24}$ showed that the expression of the evaluated eight antigens has negative impact on prognosis of ALL: CD86, CD135, CD117, CD133, CD71, CXCR4, VLA-4 and CD38+/ CD58-, and only three articles ${ }^{18,19,22}$ showed that expression of CD304, 
Table 1: Main characteristics of the individual studies analysed

\begin{tabular}{|c|c|c|c|c|c|c|}
\hline Marker & Article & JCR & Location & Design & Aim of study & STROBE \\
\hline CD27 & $\begin{array}{l}\text { Kamazani et al. } \\
\text { (Med Oncol. 2013) }^{18}\end{array}$ & 2.486 & Iran & $\begin{array}{l}\text { Cross-sectional } \\
\text { observational }\end{array}$ & $\begin{array}{l}\text { To study the prognostic importance of CD27 in patients with } \\
\text { B-cell ALL }\end{array}$ & $20(91 \%)$ \\
\hline CD200 & $\begin{array}{l}\text { Alapat et al. } \\
\left(\text { Am J Clin Pathol. 2012) }{ }^{19}\right.\end{array}$ & 2.278 & USA & $\begin{array}{l}\text { Cross-sectional } \\
\text { observational }\end{array}$ & $\begin{array}{l}\text { - To report the analysis of CD200 expression by flow cytometry in } \\
\text { - } \text { ceveral types of lymphoid malignancy; } \\
\text { - To show that although its expression is nearly uniform in B-cell } \\
\text { ALL, there is aberrant under- or over-expression of CD200 in } \\
\text { most cases of B-cell ALL compared with normal bone marrow } \\
\text { B-cell progenitors and to demonstrate that although absent in } \\
\text { normal bone marrow PCs, CD200 is expressed in most of PCMs, } \\
\text { and negativity for this marker may be associated clinically with } \\
\text { progression to more aggressive disease }\end{array}$ & $21(95.4 \%)$ \\
\hline CD86 & $\begin{array}{l}\text { Mansour et al. } \\
\text { (Leuk Lymphoma. 2014) }\end{array}$ & 3.093 & Egypt & Case control & $\begin{array}{l}\text { To evaluate the role of CD } 86 \text { and SCTLA- } 4 \text { as possible } \\
\text { immunopathogenic factors in patients with ALL and to correlate the } \\
\text { levels of these proteins with the clinical and haematologic findings, } \\
\text { response to therapy and outcome }\end{array}$ & $21(95.4 \%)$ \\
\hline CD135 & \multirow[t]{2}{*}{$\begin{array}{l}\text { Noronha et al. } \\
(\text { Blood Cells Mol Dis. 2016) }\end{array}$} & \multirow[t]{2}{*}{2.731} & \multirow[t]{2}{*}{ Brazil } & \multirow[t]{2}{*}{ Cohort } & \multirow{2}{*}{$\begin{array}{l}\text { To establish the distribution frequencies of FLT3 mutations and to test } \\
\text { the association between FLT3 status and CD135 and CD117 identified } \\
\text { by flow cytometry in paediatric T-cell ALL }\end{array}$} & \multirow[t]{2}{*}{$21(95.4 \%)$} \\
\hline CD117 & & & & & & \\
\hline CD304 & $\begin{array}{l}\text { Solly et al. } \\
\text { (Cytometry A. 2012) }^{22}\end{array}$ & 3.181 & France & Case control & $\begin{array}{l}\text { To study the CD304 expression profile of the normal B lineage and of } \\
\text { the leukaemic cells from patients with B-cell ALL, which led to suggest } \\
\text { its potential usefulness as a new marker for MRD monitoring }\end{array}$ & $21(95.4 \%)$ \\
\hline CD133 & $\begin{array}{l}\text { Tolba et al. } \\
\text { (Med Oncol. 2013) }^{10}\end{array}$ & 2.634 & USA & Cohort & $\begin{array}{l}\text { Assess CD133 expression in patients with acute myeloid or } \\
\text { lymphoblastic leukaemia and to evaluate its correlation with the different } \\
\text { clinical and laboratory data as well as its relation to disease outcome }\end{array}$ & $20(91.0 \%)$ \\
\hline CD71 & $\begin{array}{l}\text { Płoszyńska et al. } \\
\text { (Folia Histochem Cytobiol. } \\
2012)^{21}\end{array}$ & 1.060 & Poland & Cohort & $\begin{array}{l}\text { To evaluate CD71 expression on ALL cells and to follow its possible } \\
\text { clinical correlations }\end{array}$ & 19 (86.4\%) \\
\hline $\begin{array}{l}\text { CD38+/ } \\
\text { CD58- }\end{array}$ & Li et al. (Leuk Res. 2016)24 & 2.606 & China & Cohort & $\begin{array}{l}\text { To explore the relationship between combined CD38+/CD58- } \\
\text { expression patterns and prognosis }\end{array}$ & 20 (91.0\%) \\
\hline CXCR4 & \multirow[t]{2}{*}{ Ko et al. (Leuk Res. 2014) } & \multirow[t]{2}{*}{2.606} & \multirow{2}{*}{$\begin{array}{l}\text { South } \\
\text { Korea }\end{array}$} & \multirow[t]{2}{*}{ Cohort } & \multirow{2}{*}{$\begin{array}{l}\text { To prospectively analyse the expression of VLA-4 and CXCR4 and } \\
\text { evaluate their correlation with disease characteristics and clinical } \\
\text { outcome in patients with newly diagnosed ALL }\end{array}$} & \multirow[t]{2}{*}{20 (91.0\%) } \\
\hline VLA-4 & & & & & & \\
\hline
\end{tabular}

$A L L=$ acute lymphoblastic leukaemia; $C L L=$ chronic lymphocytic leukaemia; CXCR4 = CXC chemokine receptor 4; FLT3= related tyrosine kinase 3; JCR = journal citation reports; $M R D=$ minimal residual disease; $P C M S=$ plasma cell myelomas; $S C T L A-4=$ cytotoxic T-lymphocyte associated antigen-4; VLA-4 = very late antigen-4.

CD27 and CD200 has positive value on prognosis. From the five cohort studies included, three evaluated the survival in ALL with high expression of the immunophenotypic markers (Table 2). ${ }^{21,23,24}$

Regarding the poor prognostic markers, Mansour et al. showed that expression of CD86, a type I transmembrane glycoprotein expressed on the surface of antigen presenting cells, was an indicator of poor prognosis in B-cell ALL. Noronha et al. discoursed and analysed CD135 and CD117 in T-cell ALL, two members of the class III receptor tyrosine kinase family, showing that the combined expression of these two markers predicted TLX3, FLT3-ITD and IL7R gene mutations, and it is associated with unfavourable outcomes in adults and children. ${ }^{20}$ Tolba et al. evaluated the expression of CD133, a five transmembrane molecule expressed on primitive normal haematopoietic progenitors, in 30 patients with ALL, and found that its expression was significantly related to patients with chemotherapy resistance, as well as high incidence of relapse and death. ${ }^{10}$ Overexpression of transferrin receptor, CD71, in adult T-cell leukaemia, was associated with poor prognosis and less favourable outcomes in patients with precursor B-cell ALL, as observed by Płoszyńska et al. ${ }^{21}$ Ko et al. studied the expression of CXCR-4, a chemokine receptor for stromal-derived factor 1 (SDF1), and VLA-4, an integrin expressed on hematopoietic stem cells and leukemic cells in patients with $\mathrm{ALL}^{23}$ It was verified that high expression of CXCR-4 and low expression of VLA-4 were predictive for shorter DFS, concluding that these markers are associated with poor prognosis and decreased survival. Another study performed by Li et al. investigated the co-expression of CD38+/CD58-; CD38 is a highly glycosylated member of the immunoglobulin super family, and CD58 is a type II transmembrane glycoprotein. This co-expression of CD38+/CD58- in paediatric patients with Ph-negative B-cell ALL may result in poor outcomes and an increased risk of relapse. ${ }^{24}$

Immunophenotypic markers were related to good prognosis in three studies: CD304, CD27 and CD200. ${ }^{18,19,22}$ CD304, a non-tyrosine kinase vascular endothelial growth factor (VEGF) receptor, was studied by Solly et al. They demonstrated the expression of CD304 in leukaemic blasts was more frequent in TEL-AML1-positive cases. ${ }^{22}$ TEL-AML1 fusion gene is the most frequent gene recombination in paediatric B-cell ALL, and it is associated with favourable prognosis. Although the frequency of BCR-ABL was higher in the CD304+ group (32\%) compared to the CD304- group (5\%), there was no significant difference. The higher expression of CD27, a member of the tumour necrosis factor family expressed on T cells, natural killer (NK) cells and memory B cells, was associated with the TEL-AML1 genotype, and it 
Table 2: Main disease and treatment features of the individual studies

\begin{tabular}{|c|c|c|c|c|c|c|c|c|c|}
\hline Marker & $\begin{array}{l}\text { Patients } \\
\text { (n) }\end{array}$ & $\begin{array}{l}\text { Mean age } \\
\text { (range) }\end{array}$ & Classification & Treatment & Prognosis & Follow-up & Cut-off & Survival & $\begin{array}{l}\text { Gene } \\
\text { mutation }\end{array}$ \\
\hline $\mathrm{CD} 27^{18}$ & 58 & $4.9(1-16)$ & $\begin{array}{l}58 \text { B-cell ALL cases: } \\
\text { FAB L1 }(n=36) \\
\text { FAB L2 }(n=22)\end{array}$ & ALL IC-BFM 2002 protocol & Good & NR & $\begin{array}{l}>20 \% \text { of } \\
\text { gated } \\
\text { cells }\end{array}$ & NR & $\begin{array}{l}\text { TEL-AML1 and } \\
\text { hiperdiploidy }\end{array}$ \\
\hline $\mathrm{CD} 200^{19}$ & 25 & NR & $\begin{array}{l}\text { B-cell ALL }(n=20) \\
\text { T-cell ALL }(n=5)\end{array}$ & NR & Good & NR & NR & NR & TEL-AML1+ \\
\hline $\mathrm{CD} 86^{\circ}$ & 60 & $18.86(3-42)$ & $\begin{array}{l}\text { FAB L1 }(n=20) \\
\text { FAB L2 }(n=32) \\
\text { FAB L3 }(n=8)\end{array}$ & NR & Poor & $\begin{array}{l}28 \\
\text { months }\end{array}$ & $\begin{array}{l}>20 \% \text { of } \\
\text { gated } \\
\text { cells }\end{array}$ & NR & NR \\
\hline CD13520 & \multirow[t]{2}{*}{171} & \multirow[t]{2}{*}{$<19$} & \multirow{2}{*}{$\begin{array}{l}\text { ETP-ALL }(n=12) \\
\text { T-II (Pre-T) }(n=32) \\
\text { T-III (T-cortical) }(n=66) \\
\text { T-IV (T-mature) }(n=35)\end{array}$} & \multirow[t]{2}{*}{$\begin{array}{l}\text { GBTLI-ALL } 93 \text { and } 99 \\
\text { BFM ALL protocols }\end{array}$} & \multirow[t]{2}{*}{ Poor } & \multirow[t]{2}{*}{ NR } & $\begin{array}{l}\text { MFI-r = } \\
1.8 />3 \%\end{array}$ & \multirow[t]{2}{*}{ NR } & \multirow{2}{*}{$\begin{array}{l}\text { STIL-TAL1 } \\
\text { (26.4\%) } \\
\text { TLX3 (11.4\%) } \\
\text { FLT3 ITD (4.9\%) } \\
\text { IL7R mutated } \\
\text { (5.8\%) }\end{array}$} \\
\hline CD117²0 & & & & & & & $\begin{array}{l}\mathrm{MFI}-\mathrm{r}= \\
1.9 />5 \%\end{array}$ & & \\
\hline CD304 22 & 70 & $\begin{array}{l}\text { CD304+ } \\
18.2 \\
(0.75-60) \\
\text { CD304- } 17.7 \\
(0.67-64)\end{array}$ & $\begin{array}{l}\text { B-I }(n=3) \\
\text { B-II }(n=38) \\
\text { B-III }(n=8) \\
\text { B-IV }(n=1)\end{array}$ & $\begin{array}{l}\text { EORTC-58951 protocol } \\
\text { and GRAALL-2003 } \\
\text { protocol }\end{array}$ & Good & NR & MFI-r $>2.2$ & NR & $\begin{array}{l}\text { TEL/AML1 } \\
(n=6)\end{array}$ \\
\hline CD133 $3^{10}$ & 30 & $\begin{array}{l}15.8 \\
(0.75-48)\end{array}$ & NR & $\begin{array}{l}\text { Vincristine } 1.5 \mathrm{mg} / \mathrm{kg} / \\
\mathrm{m}^{3} / \text { week; doxorubicin } \\
25 \mathrm{mg} / \mathrm{m}^{3} / \text { week IV } \\
\text { infusion; L-asparaginase } \\
6000 \mathrm{u} / \mathrm{m}^{3} \mathrm{SC} \text { on; } \\
\text { prednisone } 40 \mathrm{mg} / \mathrm{m}^{3} / \text { day }\end{array}$ & Poor & $\begin{array}{l}12 \\
\text { months }\end{array}$ & $\begin{array}{l}>10 \% \text { of blast } \\
\text { cells }\end{array}$ & NR & NR \\
\hline $\mathrm{CD} 71^{21}$ & 61 & $\begin{array}{l}5.3 \\
(1.0-17.6)^{*}\end{array}$ & $\begin{array}{l}\text { B-cell ALL }(n=55) \\
\text { T-cell ALL }(n=5) \\
\text { Biphenotypic T/B ALL } \\
(n=1)\end{array}$ & ALLIC 2000 protocol & Poor & $\begin{array}{l}60 \\
\text { months }\end{array}$ & $\begin{array}{l}\mathrm{MFI}>13 \\
(\mathrm{~B}-\text { cell ALL) } \\
\mathrm{MFI}>27.9 \\
\text { (T-cell ALL) }\end{array}$ & $\begin{array}{l}\text { High } \\
\text { expression of } \\
\text { CD71 showed } \\
\text { a decrease } \\
\text { on both DFS } \\
\text { and OS }\end{array}$ & NR \\
\hline $\begin{array}{l}\text { CD38+/ } \\
\text { CD58-24 }\end{array}$ & 196 & $5(0-18)$ & $\begin{array}{l}\text { PRO B-cell ALL ( } n=9) \\
\text { COM ALL }(n=150) \\
\text { PRE B-cell ALL }(n=37)\end{array}$ & $\begin{array}{l}\text { Germany ALL (BFM-95) } \\
\text { protocols }\end{array}$ & Poor & $\begin{array}{l}80 \\
\text { months }\end{array}$ & $\begin{array}{l}>20 \% \text { of blast } \\
\text { cells }\end{array}$ & $\begin{array}{l}\text { CD38+/CD58- } \\
\text { Higher relapse } \\
\text { rate, shorter } \\
\text { independent } \\
\text { adverse } \\
\text { prognostic } \\
\text { predictor for } \\
\text { relapse }\end{array}$ & $\begin{array}{l}\text { TEL-AML1 } \\
(n=36) \\
\text { E2A-PBX1 } \\
(n=12) \\
\text { MLL } \\
\text { rearrangement } \\
(n=4)\end{array}$ \\
\hline $\mathrm{CXCR}^{23}$ & $\begin{array}{l}29 \text { adults } \\
\text { and } 25 \\
\text { children }\end{array}$ & \multirow[t]{2}{*}{$\begin{array}{l}\text { Adults: } 36 \\
(17-82)^{*} \\
\text { Children: } 5 \\
(0.25-15)^{*}\end{array}$} & \multirow[t]{2}{*}{$\begin{array}{l}\text { PRO B-cell ALL }(n=1) \\
\text { COM ALL }(n=41) \\
\text { PRE B-cell ALL }(n=5) \\
\text { T-cell ALL }(n=7)\end{array}$} & \multirow{2}{*}{$\begin{array}{l}\text { Patients from 1-10 years } \\
\text { And Ph-: vincristine, } \\
\text { dexamethasone, PEG } \\
\text { asparaginase, intrathecal } \\
\text { cytarabine, and intrathecal } \\
\text { methotrexate; } \\
\text { Other patients: vincristine, } \\
\text { prednisolone, } \\
\text { I-asparaginase, } \\
\text { daunomycin, intrathecal } \\
\text { cytarabine, } \\
\text { and intrathecal } \\
\text { methotrexate }\end{array}$} & \multirow[t]{2}{*}{ Poor } & \multirow{2}{*}{$\begin{array}{l}\text { Adults: } \\
22.6 \\
\text { months; } \\
\text { Children: } \\
21.4 \\
\text { months }\end{array}$} & $\begin{array}{l}\text { Adults: MFI } \\
\text { 71.5; } \\
\text { Children: MFI } \\
64.3\end{array}$ & \multirow{2}{*}{$\begin{array}{l}\text { LOW VLA-4 } \\
\text { and high } \\
\text { CXCR4 were } \\
\text { predictive for } \\
\text { shorter DFS } \\
\text { and OS in } \\
\text { adult ALL }\end{array}$} & \multirow[t]{2}{*}{ NR } \\
\hline VLA-4 ${ }^{\text {low23 }}$ & $\begin{array}{l}22 \text { adults } \\
\text { and } 24 \\
\text { children }\end{array}$ & & & & & & $\begin{array}{l}\text { Adults: MFI } \\
\text { 19.6; } \\
\text { Children: MFI } \\
18.4\end{array}$ & & \\
\hline
\end{tabular}

*median age

$A L L=$ acute lymphoblastic leukaemia; BFM = Berlin-Frankfurt-Münster; $C X C R 4=C X C$ chemokine receptor 4; DFS = disease-free survival; EORTC = European Organisation for Research and Treatment of Cancer; ETP-ALL = early T-cell precursor acute lymphoblastic leukaemia; FAB = French-American-British classification; IC-BFM =

InterCity Berlin-Frankfurt-Münster; GBTLI = The Brazilian Cooperative Group for Treatment of Childhood Acute Lymphocytic Leukemia; GRAALL = Group for Research on Adult Acute Lymphoblastic Leukemia; IV = intravenous; $\mathrm{MFI}=$ mean fluorescence intensity; $N R=$ not reported; OS = overall survival; $S C=$ subcutaneous;

VLA-4 = very late antigen-4. 
Table 3: Basic features of each antigen analysed on this systematic review

\begin{tabular}{|c|c|c|c|c|}
\hline Antigen & Molecular group & Function & Frequency in ALL & Prognostic impact \\
\hline CD27 & $\begin{array}{l}\text { A member of the tumour necrosis factor family, } \\
\text { expressed on T cells, NK cells, and memory B cells }\end{array}$ & $\begin{array}{l}\text { Marker for memory B cells that plays an important } \\
\text { role in lymphoid differentiation and apoptosis, and it } \\
\text { is involved in B cell maturation }\end{array}$ & B-cell ALL: $20.7 \%$ & Good \\
\hline CD200 & $\begin{array}{l}\text { Cell surface glycoprotein expressed in normal } \\
\text { B cells and some T cells }\end{array}$ & Delivers an inhibitory signal to the target cell & $\begin{array}{l}\text { B-cell ALL: 95\% } \\
\text { T-cell ALL: 0\% }\end{array}$ & Good \\
\hline CD86 & $\begin{array}{l}\text { Type I transmembrane glycoprotein expressed on } \\
\text { the surface of antigen presenting cells }\end{array}$ & $\begin{array}{l}\text { Provides signal to stimulate T cells when bound to } \\
\text { CD28, and when interacting with CTLA-4, it plays a } \\
\text { role in inducing peripheral tolerance }\end{array}$ & $65 \%$ & Poor \\
\hline CD135 & \multirow{2}{*}{$\begin{array}{l}\text { Members of the class III receptor tyrosine kinase } \\
\text { family }\end{array}$} & \multirow{2}{*}{$\begin{array}{l}\text { Collaborate to primitive haematopoietic cells normal } \\
\text { proliferation and differentiation }\end{array}$} & T-cell ALL: $11.4 \%$ & Poor \\
\hline CD117 & & & NR & Poor \\
\hline CD304 & $\begin{array}{l}\text { A non-tyrosine kinase co-receptor for semaphorins } \\
\text { and vascular endothelial growth factor }\end{array}$ & Implicated in neuronal guidance and angiogenesis & B-cell ALL: 36\% & Good \\
\hline CD133 & $\begin{array}{l}\text { A five transmembrane molecule expressed on } \\
\text { primitive normal haematopoietic progenitor }\end{array}$ & $\begin{array}{l}\text { Regeneration, proliferation and differentiation of stem } \\
\text { cells }\end{array}$ & $33.3 \%$ & Poor \\
\hline CD71 & Transferrin receptor 1 & $\begin{array}{l}\text { Uptake of cellular iron by internalisation of the ion } \\
\text { transported by transferrin }\end{array}$ & $92 \%$ & Poor \\
\hline CD38 & A 45 kDa type II transmembrane glycoprotein & $\begin{array}{l}\text { Functions as a multifunctional enzyme in the } \\
\text { production of nucleotide-metabolites }\end{array}$ & B-cell ALL: $88.27 \%$ & Poor (CD38+/CD58-) \\
\hline CXCR4 & $\begin{array}{l}\text { Receptor for stromal-derived factor } 1 \text { expressed } \\
\text { on haematopoietic stem cells }\end{array}$ & $\begin{array}{l}\text { Cell adhesion and haematopoietic stem cell niche } \\
\text { regulation }\end{array}$ & NR & Poor \\
\hline VLA-4 low & $\begin{array}{l}\text { An integrin expressed on haematopoietic stem } \\
\text { cells and leukaemic cells }\end{array}$ & Adhesive and signalling receptor & NR & Poor (low expression) \\
\hline
\end{tabular}

CTLA-4 = cytotoxic T-lymphocyte associated antigen-4; NK = Natural Killer; $N R=$ not reported.

was detected in low-risk patients and in those who entered complete remission, being significantly correlated with favourable prognosis. ${ }^{18}$ The other marker, CD200, a cell surface glycoprotein expressed in normal B cells and some T cells, was present in almost all precursor B-cell ALL with aberrant over- or under-expression when compared to normal B-cell progenitors in 55\% of cases. Four patients with B-cell ALL with the highest CD200 over-expression presented hyperdiploidy or were TEL-AML1 positive, these two subgroups are typically associated with an excellent clinical outcome. T-cell ALL cases were uniformly CD200 negative. ${ }^{19}$

\section{Meta-analysis}

Two cohorts were selected for meta-analysis since they demonstrated survival curves in their results, and it was possible to evaluate the DFS and OS at three different time points..$^{21,24}$ The results of quantitation of two immunophenotypic markers were evaluated in these two cohorts. Homogeneity and symmetry analysis showed that both relapse and death data were progressively asymmetric and heterogeneous over the study period. This is the reason we used the fixed effects model in the relapse data at 10 months and the random effects model in all other analyses.

The OS analysis at 30 and 60 months showed a great heterogeneity with Cochran $\mathrm{Q}$ test $(\mathrm{Q}=6.4635 ; \mathrm{P}=0.0911$ and $\mathrm{Q}=32.1836 ; \mathrm{P}<0.0001$, respectively). The Higgins $I^{2}$ test showed a result of $57.38 \%$ for 30 months and $97.37 \%$ for 60 months. The same analysis was applied to DFS with Cochran $Q$ test $(Q=13.1929 ; \quad P=0.0042)$ for 30 months and $(\mathrm{Q}=20.4940 ; \mathrm{P}=0.0001)$ for 60 months. The Higgins $\mathrm{I}^{2}$ test showed a result of $73.38 \%$ and $88.95 \%$ for 30 and 60 months, respectively. The tests were considered homogeneous for 10 months in OS and DFS, presenting Higgins/ ${ }^{2}$ test of $41.61 \%$ in both evaluations. The Cochran Q test presented the same result for OS and DFS $(Q=5.1487$; $\mathrm{p}=0.1612$ ).
The meta-analytic results (Figures 2 and 3 ) show a progressive relapse rate that reaches $23 \%$ in 60 months, the only one with statistical significance, as well as the death rate that reaches $23 \%$ at the same period of time.

\section{Discussion}

Identification of new immunophenotypic markers in ALL will not only enhance our prognostic abilities but it will also allow the exploration of new therapeutic targets and MRD monitoring. ${ }^{26}$ Over the last decades, some prognostic factors have been established in ALL, including age, cytogenetic abnormalities, white blood cell count and serum lactate dehydrogenase levels. ${ }^{3}$ However, further studies are needed to improve the our understanding of leukaemia cell biology, making it possible to determine new prognostic factors that will help to improve patients' follow-up and the therapeutic guidance. In this systematic review, eight new immunophenotypic markers were associated with worse outcomes in DFS and decreased OS.

\section{Cell adhesion}

VLA-4 and CXCR4 perform critical roles in the adhesion of hematopoietic and leukaemic stem cells to marrow stromal cells. They have important function on haematopoiesis regulation and in the immune system organisation, in addition, they also are expressed in leukaemia blast cells. The significance of CXCR4 and VLA-4 as clinical prognostic markers in leukaemia has been studied mainly in patients with acute myeloid leukaemia, and their expression has been associated with decreased DFS and OS. ${ }^{27}$ In ALL, Ko et al. verified that the association of high CXCR4 expression and low VLA-4 expression at diagnosis is correlated to worse prognosis in adults, showing shorter DFS and OS. ${ }^{23}$

Another adhesion molecule, CD58, is characterised by cytotoxic T-/NK-cell activation and immune recognition of tumour cells. CD58 is expressed on T cells, monocytes and erythrocytes while CD38 is very 
Figure 2: Forest plot with the proportion of individuals that relapsed in 60 months, their confidence intervals and the meta-analytic measure

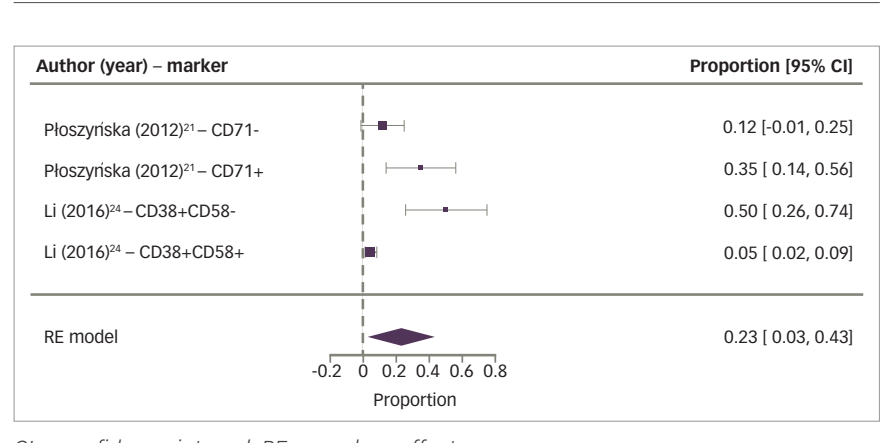

$\mathrm{Cl}=$ confidence interval; $\mathrm{RE}=$ random-effects

Figure 3: Forest plot with the proportion of individuals that died in 60 months, their confidence intervals and the metaanalytic measure

\begin{tabular}{|c|c|c|}
\hline Author (year) - marker & & Proportion $[95 \% \mathrm{Cl}]$ \\
\hline Płoszyniska (2012)21 - CD71- & 1 & $0.04[-0.04,0.12]$ \\
\hline Płoszyniska (2012)21 - CD71+ & $\longmapsto$ & $0.20[0.02,0.38]$ \\
\hline Li (2016) ${ }^{24}-\mathrm{CD} 38+\mathrm{CD} 58-$ & $\longmapsto$ & $0.69[0.46,0.91]$ \\
\hline Li (2016) & 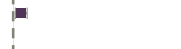 & $0.05[0.02,0.09]$ \\
\hline \multirow[t]{2}{*}{ RE model } & 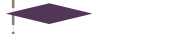 & $0.23[-0.05,0.51]$ \\
\hline & $\begin{array}{c}0.20 .40 .60 .8 \\
\text { Proportion }\end{array}$ & \\
\hline
\end{tabular}

$\mathrm{Cl}=$ confidence interval; $\mathrm{RE}=$ random-effects

present during B-cell ontogeny. CD38 appears on bone marrow precursor cells but is lost on mature lymphocytes. ${ }^{28} \mathrm{Li}$ and collaborators found that the CD38+/CD58- phenotype in patients with ALL is implicated in disease course, leading to a decrease on OS and DFS. In addition, CD38+/CD58phenotype has been considered as an independent adverse prognostic factor that can be identified in high-risk patients at diagnosis. Otherwise, an increase in OS and DFS was identified in patients with ALL with CD38+/ CD58+ expression, resulting in a better outcome. ${ }^{24}$

\section{Programmed cell death}

CD86 is a protein expressed on antigen presenting cells that deliveries costimulatory signals essential to T-cell activation and survival. CD86 acts on apoptosis regulation, and its high expression has been associated with leukaemic blast cell survival by programmed cell death inhibition. A decrease in OS was found in patients with ALL that express high levels of CD86. On the other hand, lower levels of this marker were associated with less relapse or death.?

CD27, a memory B cell marker, participates in lymphoid differentiation and maturation, beyond this, it plays an important role in apoptosis as a cell-death regulator. Kamazani et al. showed in their study that higher expression of CD27 was detected in low-risk patients and in those who entered complete remission, being significantly correlated with favourable prognosis. ${ }^{18}$

\section{Proliferation and differentiation}

CD133 expression is associated with regeneration, proliferation and differentiation of stem cells. Studies revealed that CD133 is a primitive normal haematopoietic progenitor marker, more specific than CD34. Patients with ALL with CD133 expression on blast cells present a more immature phenotype, and they are associated with an unfavourable prognosis. ${ }^{29,30}$ A meta-analysis conducted by our research group showed that CD133 expression was also associated with decreased OS, being considered as a poor prognostic factor in acute myeloid leukaemia. ${ }^{10,31}$ It was demonstrated by Tolba et al. that the expression of CD133 in ALL cases also has a negative impact leading to higher resistance to standard chemotherapy and higher relapse and death rates. This way, CD133 expression is an independent prognostic factor associated with poor prognosis in patients with ALL. ${ }^{10}$

Noronha et al. discoursed and analysed CD135 and CD117, receptors highly expressed in lymphoid and myeloid early cell populations that promote the growth and differentiation of primitive haematopoietic cells. ${ }^{20}$ CD117 was found with higher frequency than CD135, and the co-expression of these two markers can predict FLT-ITD mutation. Although FLT-ITD mutation occurs at low frequency in children with T-cell ALL, it is possible to predict it by multiparametric flow cytometry analysis of these two markers in the panel of monoclonal antibodies. This makes it possible to screen and identify patients who would benefit from treatment with inhibitors of tyrosine kinase. ${ }^{20}$

\section{Markers with other functions}

CD304 plays an important role in various biological processes, including angiogenesis, binding to VEGF, axonal guidance, tumorigenesis and immunologic response. ${ }^{32}$ Solly and collaborators identified this marker as a promising target for anti-leukaemic and antiangiogenic treatment strategies in patients with leukaemia, and as an MRD marker that could be applicable in a large subset of patients with B-cell ALL. The better understanding of the biological function of CD304 can include it as a prognostic factor or therapeutic target. ${ }^{22}$ Other groups have confirmed the overexpression of CD304 as an important MRD marker. ${ }^{33,34}$ More recently, the EuroFlow Consortium added CD304 antigen in B-cell ALL MRD evaluation by next-generation flow cytometry. ${ }^{35}$

CD71 is highly expressed on the surface of cells of the erythroid lineage and weakly expressed in ALL and diffuse large B-cell lymphoma. ${ }^{36}$ CD71 was included in a study performed by Płoszyńska et al., and it was demonstrated that CD71 was present on lymphoblasts of almost all cases of ALL. Its expression was statistically higher on T-lineage ALL than B-lineage ALL. Despite no statistical difference found, it was observed that the DFS and OS were shorter in patients with B-lineage ALL with CD71 over-expression. ${ }^{21}$

Interaction between CD200-CD200R acts on regulation of immune responses, myeloid differentiation and/or activation, foetal loss and transplant rejection. ${ }^{37}$ CD200 suppresses the myeloid-cell functions, such as neutrophils and macrophages, by binding to the CD200 receptor and stimulating differentiation into the regulatory T-cell subset. ${ }^{38}$ Alapat and collaborators conducted a study that showed CD200 expression is associated with precursor lymphoid malignancies, being negative in most T-cell ALL cases and positive in about 95\% of B-cell ALL cases. It was reported in this study that hyperdiploidy and TEL-AML1, genetic alterations that are typically associated with an excellent clinical outcome, were present in all B-cell ALL cases when CD200 over-expression was observed, making it a potential therapeutic target. ${ }^{19}$ Clinical trials using samalizumab, a humanised monoclonal antibody that blocks CD200, are been conducted in patients with advanced solid tumours and acute myeloid leukaemia. ${ }^{39}$

Regarding the meta-analytic estimate, immunophenotypic markers are not related to each other, since their pathogenicity is not necessarily 
associated; making them independent prognostic factors. A forest plot was conducted with the relative risks and their confidence intervals from the relapse and death rates. This demonstrated that Płoszyńska's study presented the highest sample number, and consequently the highest number of events. ${ }^{21}$ The studies of Płoszyńska et al. ${ }^{21}$ and Li et al. ${ }^{24}$ presented significant differences between both studies, observed by a shift to the right on the horizontal line that represents 95\% confidence interval, and the vertical line that represents the relative risks (Figures 2 and 3). Despite high heterogeneity, this analysis showed an increasing relapse rate of $23 \%$ at 60 months. Analysis of the individual studies did not reach statistical relevance, however after compiling the results of the two studies, the meta-analysis, represented by the diamond on the forest plot, proved that null hypothesis is not true, confirming that CD71+ and CD38+/CD58- phenotypes are associated to increased relapse and death risks. The diamond's shift to the right and close to number 1 showed a positive correlation in which the presence of CD71 and absence of CD58 expression (CD38+/CD58-) is associated with a relative risk of relapse and death rates (Figures 2 and 3 ).

In the first 2 years, DFS showed a progressive relapse when there was the expression of CD71+ and CD38+/CD58-, but only at 60 months did CD38+/ CD58- show a significant difference. Nonetheless, CD71+ expression in OS analysis was not proportional to relapse since it was observed that there was response to treatment after relapse, maintaining mortality rates lower than relapse rates. On the other hand, in the first and third years, the expression of CD38+/CD58- also resulted in no significant increase in mortality rate, but the number of relapses was proportional to deaths. In addition, the mortality rate at 60 months was two-times greater than the survival rate.
Through comparative analysis of these two markers, the CD38+/ CD58- phenotype was more associated with unfavourable prognosis than CD71+, being related to low OS at 60 months. Thus, CD38+/CD58phenotype is a medium-term predictor of mortality for patients with ALL.

\section{Strengths and limitations}

The strengths of this analysis include a wide search covering more than 10,000 articles; applying stringent criteria that resulted in few relevant articles; comprising populations of different races/ethnicities from a wide geographic range; journals with high impact factors; and STROBE scores of $>90 \%$ for almost all articles, revealing a high methodological quality. The study also has limitations regarding criteria to determine positive or negative antigen expression that varied across the included studies and the low number of cases in some studies. Survival in formation was extracted from survival curves and not from a mortality table. The search only included articles published in English, Spanish and Portuguese, and may have missed relevant publications in other languages.

\section{Conclusion}

In conclusion, this study provides information regarding the independent prognostic factors that could be included into clinical protocols, aiding risk stratification and therapeutic guidance for ALL. The meta-analysis revealed that expression of CD38+/CD58-incurs an increased relapse rate of $23 \%$ at 60 months. This finding led to the conclusion that the CD38+/CD58- phenotype can be considered a predictor of mortality for patients with ALL. More studies are needed to confirm these findings. $\square$
1. Barwe $S P$, Quagliano A, Gopalakrishnapillai A. Eviction from the sanctuary: development of targeted therapy against cell adhesion molecules in acute lymphoblastic leukemia. Semin Oncol. 2017;44:101-12.

2. Miller KD, Siegel RL, Lin CC, et al. Cancer treatment and survivorship statistics, 2016. CA Cancer J Clin. 2016;66:271-89.

3. Inaba $H$, Greaves $M$, Charles $G$, et al. Acute lymphoblastic leukemia. Lancet. 2013;381:1943-55.

4. Arber DA, Orazi A, Hasserjian R, et al. The 2016 revision to the World Health Organization classification of myeloid neoplasms World Health Organization classification of myeloid
and acute leukemia. Blood. 2016;127:2391-405.

5. Finak $G$, Langweiler $M$, Jaimes $M$, et al. Standardizing flow cytometry immunophenotyping analysis from the human immunophenotyping consortium. Sci Rep. 2016;6:20686.

6. Van Dongen JJM, Orfao A. EuroFlow: resetting leukemia and lymphoma immunophenotyping. Basis for companion diagnostics and personalized medicine. Leukemia. 2012;26:1899-907.

7. Ahmad IN, Assad S, Rahman M, et al. Flow cytometric analysis: four-year experience in a tertiary care centre of Pakistan. Cureus. 2016;8:1-10.

8. Fossat C, Roussel M, Arnoux I, et al. Methodological aspects of minimal residual disease assessment by flow cytometry in acute lymphoblastic leukemia: a French multicenter study. in acute lymphoblastic leukemia: a Fre9
cytometry B Clin Cytom. 2015;88:21-9.

9. Mansour A, Elkhodary T, Darwish A, et al. Increased expression of costimulatory molecules CD86 and SCTLA-4 in patients with acute lymphoblastic leukemia. LeukLymphoma. 2014;55:2120-24.

10. Tolba FM, Foda ME, Kamal HM, et al. Expression of CD133 in acute leukemia. Med Oncol. 2013;30:527-34.

11. Lee-Sherick $A B$, Linger RMA, Gore $L$, et al. Targeting paediatric acute lymphoblastic leukemia: novel therapies currently in development. Br $\mathrm{J}$ Haemato 2010;151:295-311

12. Moher D, Liberati A, Tetzlaff J, et al. Preferred reporting items for systematic reviews and meta-analyses: the PRISMA statement Ann Intern Med. 2009;151:264-69.

13. Van Dongen JJM, Lhermitte L, Bottcher S, et al. EuroFlow antibody panels for standardized n-dimensional flow cytometric immunophenotyping of normal, reactive and malignant leukocytes. Leukemia. 2012;26:1908-75. and malignant leukocytes. Leukemia. 2012;26:1908-75.
4. Vandenbroucke JP, Von Elm E, Altman DG, et al. Strengthening the Reporting of Observational Studies in Epidemiology (STROBE): explanation and elaboration. Epidemiology. 2007; 18:805-35.

15. Sagi A, Collord G, Stanley WKNG, et al. Prediction of acute myeloid leukaemia risk in healthy individuals. Nature. 2018;559:400-4.

16. R. Core Team. R: A language and environment for statistical computing. R Foundation for Statistical Computing, Vienna, Austria, 2018. Available at: www.R-project.org/ (accessed 26 February 2018)

17. Viechtbauer $W$. Conducting meta-analyses in $\mathrm{R}$ with the metafor package. J Stat Softw. 2010;36:1-48.

18. Kamazani FM, Bahoush GR, Aghaeipour M, et al. CD44

and CD27 expression pattern in B cell precursor acute and CD27 expression pattern in B cell precursor acute lymphoblastic le

19. Alapat $D$, Coviello-Malle JM, Owens R, et al. Diagnostic usefulness and prognostic impact of CD200 expression in lymphoid malignancies and plasma cell myeloma. Am I ClinPathol. 2012;137:93-100.

20. Noronha EP, Andrade FG, Zampier C, et al. Immunophenotyping with CD135 and CD117 predicts the FLT3, IL-7R and TLX3 gene mutations in childhood T-cell acute leukemia. Blood Cells Mol Dis. 2016;57:74-80.

21. Płoszyńska A, Ruckemann-Dziurdzińska K, Jóźwik A et al. Cytometric evaluation of transferrin receptor (CD71) in childhood acute lymphoblastic leukemia. Folia Histochem Cytobiol. 2012;50:304-11.

22. Solly $F$, Angelot $F$, Garand R, et al. CD304 is preferentially expressed on a subset of $B$-lineage acute lymphoblastic leukemia and represents a novel marker for minimal residual disease detection by flow cytometry. Cytometry $A$. 2012;81:17-24

23. Ko SY, Park CJ, Park SH, et al. High CXCR4 and low VLA-4 expression predicts poor survival in adults with acute Iymphoblastic leukemia. Leuk Res. 2014;38:65-70.

24. Li XM, Zhang LP, Wang YZ, et al. CD38+ CD58- is an independent adverse prognostic factor in paediatric Philadelphia chromosome negative B cell acute lymphoblastic leukaemia patients. Leuk Res. 2016;43:33-8.

25. Möricke A, Reiter A, Zimmermann M, et al. Risk-adjusted therapy of acute lymphoblastic leukemia can decrease treatment burden and improve survival: treatment results of 2169 unselected pediatric and adolescent patients enrolled in 2169 unselected pediatric and adolescent patients
the trial ALL-BFM 95. Blood. 2008;111:4477-89.

26. Ding M, Kaspersson K, Murray D, et al. High-throughput flow cytometry for drug discovery: principles, applications, and cas studies. Drug Discov Today. 2017;22:1844-50.

27. Mannelli F, Cutini I, Gianfaldoni $G$, et al. CXCR4 expression accounts for clinical phenotype and outcome in acute myeloid leukemia. Cytometry Part B - Clin Cytom. 2014;86:340-49.
28. Hamblin TJ. CD38: what is it there for? Blood. 2003;102:1939-40.

29. Ji H, Chen L, Dai Y, et al. Aberrant expression of CD133 and CD82 in patients with pediatric acute lymphoblastic leukemia and the clinical significance. Oncol Lett. 2017;14:5811-18.

30. Cox CV, Diamanti P, Evely RS, et al. Expression of CD133 on leukemia-initiating cells in childhood ALL. Blood. 2017:113:3287-96.

31. Costa AF, Menezes DL, Pinheiro LHS, et al. Role of new immunophenotypic markers on prognostic and overall survival of acute myeloid leukemia: a Systematic Review and survival of acute myeloid leukemia: a Syst
Meta-Analysis. Sci Rep. 2017;7:4138.

32. Abaza HM, Alfeky MAA, Eissa DS, et al. Neuropilin-1/ CD304 expression by flow cytometry in pediatric precurso b-acute lymphoblastic leukemia: a minimal residual disease and potential prognostic marker. J Pediatr Hematol Oncol. 2018;40:200-7

33. Meyerson HJ, Blidaru G, Edinger A, et al. NRP-1/CD304 expression in acute leukemia: a potential marker for minimal residual disease detection in precursor B-cell acute lymphoblastic leukemia. Am I Clin Pathol. 2012;137:39-50

34. Sędek L, Theunissen P, Costa ES, et al. Differential expression of CD73, CD86 and CD304 in normal vs. leukemic B-cell precursors and their utility as stable minimal residual disease markers in childhood B-cell precursor acute disease markers in childhood B-cell precursor acute lymphoblastic leukemia. J Immu

35. Theunissen P, Mejstrikova E, Sedek L, et al. Standardized flow cytometry for highly sensitive MRD measurements in B-cell acute Iymphoblastic leukemia. Blood. 2017;129:347-57.

36. Dong HY, Wilkes $\mathrm{S}$, Yang H. CD71 is selectively and ubiquitously expressed at high levels in erythroid precursors of all maturation stages: a comparative immunochemical study with glycophorin A and hemoglobin A. Am I Surg Pathol. 2011;35:723-32.

37. Aref S, Azmy E, EL-Bakry K, et al. Prognostic impact of CD200 and CD56 expression in adult acute lymphoblastic leukemia patients. Hematology. 2017;22:1-8.

38. Kong T. Park JM, Jang JH, et al. Immunomodulatory effect of CD200-positive human placenta-derived stem cells in the early phase of stroke. Exp Mol Med. 2018;50:e425

39. U.S. National Library of Medicine, study of biomarker-based treatment of acute myeloid leukemia, 2019. Available at: www.clinicaltrials.gov/ct2/show/study/ NCT03013998?term $=$ samalizumab\&rank $=2$ (accessed 27 February 2018) 